\title{
The Relationship Between Library Users' Perception And Satisfaction On Library Services At The Center Of Information And Library Resources (Cisral) Of Padjadjaran University
}

\section{Hubungan Persepsi Pemustaka Dengan Kepuasan Pemustaka Pada Layanan Perpustakaan Di Center Of Information Secientific Resources And Library (Cisral)}

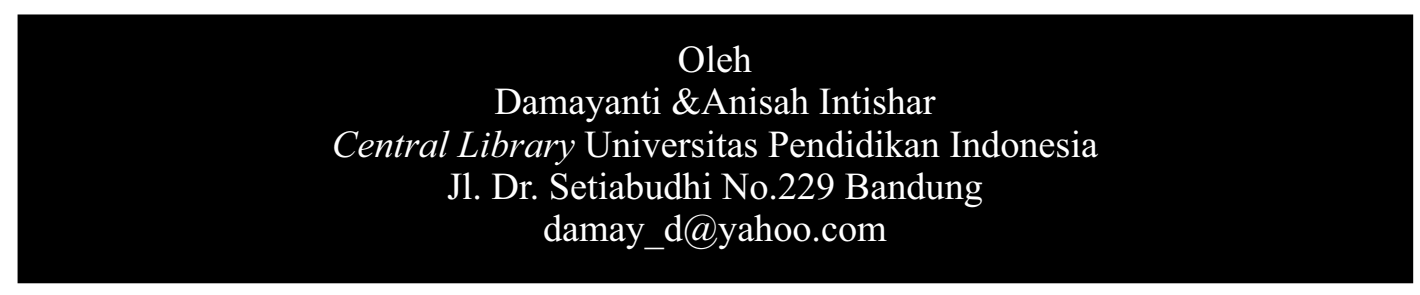

Abstract. This research was conducted to address the diverse array of types of services provided by Padjadjaran University Library for its users. The main problem of this research is users' satisfaction on reference services of Centre of Information Scientific Resources and Library (CISRAL) of Unpad. The study focused on one of the factors that connect users' satisfaction on CISRAL reference services in reference services department. Therefore, this research aimed to find out the relationship between library users' perception on reference services and library users' satisfaction on Reference Services of CISRAL Unpad. This research consisted of two variables. users' perception towards reference services ( $X$ variable) and users' satisfaction on reference services department ( $Y$ variable). Both users' perception and satisfaction were measured using four indicators: collection availability, the competencies of service librarians, the facilities of reference service, and the room layout of the reference service room. The population was visitors of reference service of CISRAL Unpad and the sample as 135 respondents which was taken as total sampling.

This research used descriptive correlational method. The data was collected using closed questionnaire that used five point Likert Scale with correlation analysis. The data analysis showed that there was a moderate correlation between users' perception towards reference services and users' satisfaction with reference service of CISRAL Unpad. The results of hypothesis testing suggested that there was a strong relationship between users' perception towards collection availability and the competencies of service librarians and users' satisfaction with reference service of CISRAl Unpad. Also, there was a very strong relationship between users' perception towards the facilities and room layout of the reference service and users' satisfaction with the reference service department of CISRAL Unpad.

Keywords: library users' perception, library users' satisfaction, library services.

\begin{abstract}
Abstrak. Hubungan antara Persepsi Pemustaka tentang Layanan Sirkulasi Mandiri dan Tingkat
Penelitian ini dilatarbelkangi oleh beraneka ragamnya jenis pelayanan yang diberikan oleh perpustakaan untuk para pemustaka di Perpustakaan Universitas Padjadjaran. Pokok permasalahan dalam penelitian ini adalah kepuasan pemustaka pada bagian layanan referensi Centre Of Information Scientific Resources And Library (CISRAL) Unpad. Inti kajiannya difokuskan pada salah satu faktor yang menghubungkan kepuasan pemustaka layanan referensi CISRAL Unpad pada bagian layanan referensi. Berdasarkan hal tersebut, pokok masalah yang diungkapkan dalam penelitian ini adalah Bagaimana Hubungan Persepsi Pemustaka Tentang Layanan Referensi dengan Kepuasan Pemustaka pada bagian Layanan Referensi di CISRAL Unpad. Penelitian ini terdiri dari dua variabel yaitu: variabel $(\mathrm{X})$ persepsi pemustaka tentang layanan referensi dan variabel (Y) kepuasan pemustaka pada bagian layanan referensi. Persepsi pemustaka dan kepuasan pemustaka diukur melalui empat indikator, yaitu: ketersediaan koleksi, kompetensi pustakawan layanan, fasilitas layanan referensi, dan tata ruang layanan referensi perpustakaan. Populasi dalam penelitian ini adalah pengunjung layanan referensi CISRAL Unpad dengan sampel 135 responden
\end{abstract}


yang dihitung berdasarkan total sampling. Metode penelitian menggunakan metode deskripitif korelasional. Teknik pengumpulan data menggunakan angket tertutup dengan skala lima kategori likert dengan analisis korelasi. Berdasarkan analisis data dapat diketahui persepsi pemustaka tentang layanan referensi berhubungan sedang dengan kepuasan pemustaka pada bagian layanan referensi di CISRAL Unpad. Hasil pengujian hipotesis menunjukkan persepsi pemustaka tentang ketersediaan koleksi dan kompetensi pustakawan layanan dengan kepuasan pemustaka pada bagian layanan referensi di CISRAL Unpad berhubungan kuat, sementara persepsi pemustaka tentang fasilitas dan tata ruang layanan referensi dengan kepuasan pemustaka pada bagian layanan referensi di CISRAL Unpad berhubungan sangat kuat.

Kata Kunci: persepsi pemustaka, kepuasan pemustaka, layanan perpustakaan. 


\section{PENDAHULUAN}

$\mathrm{P}$ erguruan tinggi adalah tempat orang berinteraksi untuk m e n i m b a, berbag i, menerapkan, dan mengembangan ilmu. Keseluruhan aktifitas ini berkaitan dan diperlukan untuk perkembangan ilmu pengetahuan. Seperti yang dijabarkan dalam Undang-Undang No. 20 tahun 2003 pasal 24 ayat (2) sebagai berikut:..."hakekat kehadiran perguruan tinggi terjabarkan dalam Tri Dharma perguruan tinggi, yaitu pendidikan, penelitian, dan pengabdian pada masyarakat". Perguruan tinggi memiliki tanggung jawab untuk menyampaikan pengetahuan (to inform) kepada mahasiswa untuk dihafalkan dan dilestarikan. Tujuan dari semua aspek Tri Dharma perguruan tinggi tersebut bertujuan untuk membentuk para mahasiswa menjadi suatu pribadi yang dapat mengembangkan potensi dirinya serta berpikir kritis sehingga mereka memiliki kemampuan dalam memecahkan setiap masalah kehidupan yang dihadapi serta mampu menghadapi tugas-tugas masa depan yang semakin kompleks. Salah satu upaya perguruan tinggi untuk mencapai tujuan perguruan tinggi tersebut yaitu dengan menyediakan layanan perpustakaan.

Perpustakaan perguruan tinggi merupakan sebuah intitusi penting dari suatu perguruan tinggi, karena perpustakaan sebagai suatu pusat sumber informasi yang melayani semua fungsi Tri Dharma Perguruan Tinggi. Oleh karena itu dapat dikatakan bahwa nilai suatu Lembaga Pendidikan Tinggi dalam mengemban ilmu pengetahuan tergantung pada kelengkapan dan kesempurnaan layanan yang diberikan oleh perpustakaan.

Layanan perpustakaan merupakan hal yang paling penting dan inti kegiatan perpustakaan. Secara umum, layanan pemustaka didefinisikan sebagai aktivitas perpustakaan dalam memberikan layanan kepada pemustaka. Pelayanan perpustakaan merupakan faktor penting yang harus mendapat perhatian dari para pengelola perpustaakaan perguruan tinggi. Pelayanan yang baik diharapkan dapat menciptakan kepuasan kepada para pemustaka. Pelayanan yang baik akan mempengaruhi seluruh aspek perpustakaan baik peningkatan persepsi perpustakaan maupun terciptanya kepuasan para pemustaka.

Untuk mewujudkan pelayanan yang baik tersebut perpustakaan semestinya mampu mengimbangi perkembangan ilmu pengetahuan, budaya, teknologi informasi dan aspek lainnya. Pemikiran terhadap perpustakaan sebagai institusi konvensional harus mulai dikikis, termasuk tentang masalah pelayanan perpustakaan dimana pelayanan yang disajikan harus merupakan pelayanan yang berorientasi kepada para pemustaka.

Pelayanan yang berorientasi pada 
pemustaka terdapat beberapa macam. Layanan-layanan itu antara lain sirkulasi, layanan referensi, layanan pendidikan pemakai, layanan penelusuran informasi, layanan penyebaran informasi terbaru, layanan penyebaran informasi terseleksi, layanan fotokopi, semua macam layanan ini harus diberikan dengan baik.

Pelayanan yang baik dapat dicapai bila dikelola oleh petugas yang memiliki kompetensi hard skill (misalnya kemampuan yang dimiliki pustakawan) dan soft skill (misalnya keramahannya pustakawan). Selain itu pelayanan yang baik dapat dicapai pula bila koleksi yang disajikan sesuai dengan kebutuhan pemustaka.

Kebutuhan informasi merupakan bagian kehidupan seseorang untuk menambah wawasan dan ilmu pengetahuan, mengembangkan profesionalitas, meluaskan bidang usaha yang dikelola atau memenuhi keinginan rasa ingin tahu seseorang terhadap sesuatu hal. Untuk memenuhi kebutuhan informasi salah satunya dengan mengunjungi perpustakaan.

Upaya untuk memenuhi kebutuhan informasi di perpustakaan dapat dilakukan melalui membuat inovasiinovasi terbaru mengenai bentuk layanan yang akan diberikan kepada pemustaka. Dengan begitu akan menimbulkan suatu kesan atau persepsi yang bermacammacam dari pemustaka. Hal ini senada dengan pengertian persepsi menurut
Suwarno (2008:hlm.53) adalah sebagai berikut:

"Persepsi pada hakekatnya adalah proses kognitif yang dialami setiap orang ketika berusaha memahami informasi yang diterimanya. Kunci untuk memahami persepsi itu merupakan suatu penafsiran yang unik terhadap situasi dan suatu pencatatan yang benar terhadap situasi”.

Selain itu, persepsi dapat diartikan sebagai proses menerima, menyeleksi, mengorganisasikan, mengartikan, menguji dan memberikan reaksi kepada rangsangan panca indera atau data, seperti yang dikemukakan oleh Pareek (1991:hlm.13) berikut ini: "Perception can be defined as process by which individuals organize and interpret their sensory imressions in order to give meaning to their environement". Pengertian persepsi tersebut menjelaskan bahwa persepsi merupakan suatu proses individu-individu mengorganisasikan dan menafsirkan sensor sensitifitas yang ada di dalam diri individu tersebut dalam merespon serta memaknai suatu kejadian atau fenomena yang terjadi di lingkungan sekitar.

Menurut Suwarno (2009: hlm.52), "persepsi dapat didefinisikan sebagai suatu proses membuat penilaian atau membangun kesan mengenai berbagai macam hal yang terdapat di dalam lapangan penginderaan seseorang". Berdasarkan pengertian tersebut maka 
pengertian persepsi dapat disimpulkan sebagai proses diterimanya rangsang berupa objek, kualitas hubungan antar gejala, maupun peristiwa sampai rangsangan itu disadari dan di mengerti.

Oleh karena itu setiap perpustakaan perguruan tinggi berupaya untuk menyajikan layanan yang terbaik kepada para pemustaka, agar tercipta persepsi yang baik terhadap layanan tersebut. Perpustakaan perguruan tinggi yang terus berupaya menyajikan layanan yang baik yaitu di CENTER OF INFORMATION SCIENTIFIC RESOURCES AND LIBRARY (CISRAL) UNIVERSITAS PADJADJARAN.

Salah satu pelayanan CISRAL Unpad adalah bagian referensi. Bagian referensi merupakan kegiatan pokok karena menyajikan koleksi referensi kepada para pemustaka. Koleksi referensi dapat membantu pemustaka menemukan informasi dengan memberikan pertanyaan-pertanyaan kepada pustakawan.

CISRAL Unpad melalui bagian referensi berkomitmen untuk menyediakan sarana dan fasilitas media edukasi serta koleksi rujukan untuk menunjang akademik. Koleksi yang ada antara lain tesis, disertasi, kamus, ensiklopedi, hasil penelitian, handbook, bibliografi, sumber biografi, indeks dan abstrak, buku pedoman, direktori, almanac, buku tahunan, sumber-sumber ilmu bumi, terbitan pemerintah, sejarah, budaya, data statistik, koleksi Jepang, koleksi perpustakaan, dan kabulah (koleksi lama yang dikeluarkan oleh seorang guru besar dari Unpad).

Untuk menciptakan layanan yang baik dilakukan dengan cara memberikan pelayanan yang cepat tanggap akan kebutuhan pemustaka. Selain itu juga ketersediaan alat penelusuran, dan penyediaan fasilitas yang baik pada perpustakaan layanan bagian referensi, kelengkapan koleksi, dan kemutakhiran koleksi referensi, pemanfaatan bagian referensi. Dengan memberikan layanan tersebut akan memberikan nilai positif mengenai layanan bagian referensi. Sehingga akan menimbulkan persepsi yang baik.

Pemanfaatan perpustakaan bagian layanan referensi CISRAL Unpad pada saat ini belum optimal hal ini dikuatkan pula oleh pendapat beberapa pemustaka bagian layanan referensi yang diwawancara bahwa terdapat aspek-aspek layanan yang belum memuaskan mereka seperti alat penelusuran $O P A C$ yang tidak berfungsi dan ventilasi yang belum memadai.

Bila aspek-aspek tersebut dibiarkan dapat menumbuhkan persepsi negatif berupa ketidakpuasan dari para pemustaka, misalnya pada ketersediaan koleksi yang tidak relevan, tidak mutakhir, pustakawan yang tidak cepat tanggap dan fasilitas yang tidak memadai, dengan begitu akan menimbulkan kesan 
atau persepsi yang negatif mengenai layanan perpustakaan bagian referensi.

Selain itu terjadinya ketidakpuasan dari pemustaka dapat dilihat pula dari ketersediaan koleksi yang tidak relevan, tidak mutakhir, dan ketidak lengkapan koleksi. Hal-hal tersebut dapat menimbulkan kesan/persepsi pemustaka yang tidak baik mengenai kepuasan terhadap layanan yang diberikan oleh Perpustakaan CISRAL Unpad.

Persepsi yang tidak baik pada bagian layanan referensi dapat menimbulkan kesan/ persepsi negatif misalnya, petugas perpustakaan bagian layanan referensi kurang ramah dan koleksi referensi yang tidak lengkap. Dengan demikian dapat dikatakan bahwa persepsi pemustaka yang baik terhadap perpustakaan bagian layanan referensi CISRAL dapat menunjukkan kepuasan pemustaka terhadap layanan tersebut.

Dalam memperoleh persepsi kepuasan pemustaka perpustakaan layanan bagian referensi CISRAL Unpad diperoleh melalui pendapat para civitas akademika Unpad (dosen, mahasiswa, dan karyawan yang menjadi anggota, serta non civitas akademika yaitu pengunjung non Unpad). Adapun data kunjungan pemustaka ke perpustakaan layanan bagian referensi CISRAL Unpad pada bulan Januari 2013 sampai bulan Mei 2013, kunjungan pemustaka mengalami peningkatan dengan rincian sebagai berikut: Januari sebanyak 108 pengunjung, bulan Februari sebanyak 110 pengunjung, bulan Maret sebanyak 121 pengunjung, bulan April sebanyak 124 pengunjung dan bulan Mei sebanyak 212 pengunjung.

Dari data kunjungan selama lima bulan tersebut diperoleh rata-rata pengunjung perbulan yaitu sebanyak 135 orang pemustaka. Bila dibandingkan dengan jumlah anggota CISRAL Universitas Padjadjaran yang berjumlah 9686 orang, maka persentase rata-rata pengunjung perpustakaan layanan bagian referensi CISRAL Unpad tersebut sangat kecil yaitu mencapai 1,39\%.

Berdasarkan uraian diatas, penulis tertarik untuk melakukan penelitian tentang "Hubungan persepsi pemustaka dengan kepuasan pemustaka pada perpustakaan layanan bagian referensi di Di Center Of Information Scientific Resources And Library (CISRAL) Universitas Padjadjaran" (Deskriptif korelasional pada bagian perpustakaan layanan bagian referensi CISRAL Unpad).

Pembahasan hasil penelitian secara khusus mendeskripsikan 4 hal yaitu: (1) Hubungan persepsi pemustaka tentang ketersediaan koleksi referensi dengan kepuasan pemustaka; (2) Hubungan persepsi pemustaka tentang kemampuan pustakawan dalam memberikan pelayanan bagian referensi dengan kepuasan pemustaka; (3) Hubungan persepsi pemustaka tentang fasilitas layanan bagian referensi dengan kepuasan 
pemustaka. (4) Hubungan persepsi pemustaka tentang tata ruang layanan dengan kepuasan pemustaka. Sementara secara umum ditujukan untuk memperoleh gambaran tentang (5) hubungan persepsi pemustaka pada layanan bagian referensi dengan kepuasan pemustaka terhadap layanan bagian referensi CISRAL Unpad.

1) Hubungan persepsi pemustaka tentang ketersediaan koleksi referensi dengan kepuasan pemustaka;

Pernyataan yang menunjukkan hubungan ketersediaan koleksi mengenai rujukan non cetak mendapatkan respon paling tinggi. Hal ini menunjukkan bahwa layanan bagian referensi CISRAL Unpad memiliki koleksi rujukan non cetak yang baik. Sedangkan pernyataan kemutakhiran koleksi yang tersedia mendapatkan respon paling rendah hal ini menujukkan bahwa koleksi yang terdapat pada layanan bagian referensi CISRAL Unpad tidak mutakhir yang berarti koleksi-koleksi tersebut kurang up to date.

Penjelasan diatas sesuai dengan teori yang dikemukakan oleh Yuyu-Yulia (2009: hlm.124) "karya non cetak meliputi bahan pustaka, dimana informasi yang disampaikannya bisa dalam bentuk suara, gambar, teks, dan juga kombinasi dua atau tiga bentuk diatas". Teori tersebut menunjukkan bahwa perpustakaan tidak hanya menyediakan koleksi tercetak, tetapi menyediakan pula koleksi non cetak. Hal ini dikarenakan semakin canggihnya era teknologi saat ini sehingga menuntut perpustakaan untuk dapat memenuhi kebutuhan pemustakanya dengan memiliki koleksi rujukan non cetak.

2) Hubungan persepsi pemustaka tentang kemampuan pustakawan dalam memberikan pelayanan bagian referensi dengan kepuasan pemustaka; Pernyataan yang menunjukkan hubungan kemampuan pustakawan mengenai keramahan pustakawan dalam memberikan pelayanan mendapatkan respon paling tinggi. Hal ini menunjukkan bahwa layanan bagian referensi CISRAL Unpad telah memberikan pelayanan yang ramah. Sedangkan pernyataan kemutakhiran koleksi yang tersedia mendapatkan respon paling rendah. Hal ini menujukkan bahwa koleksi yang terdapat pada layanan bagian referensi CISRAL Unpad tidak mutakhir yang berarti koleksi-koleksi tersebut kurang up to date.

Hasil diatas sesuai dengan Permendiknas No. 25 Tahun 2008 mengenai kompetensi kepribdian, dimana salah satu point tersebut adalah ramah. Keramahan pustakawan dibutuhkan untuk membantu pemustaka dalam mencari koleksi referensi sehingga dapat memberikan rasa kenyamanan pada pemustaka. 
3) Hubungan persepsi pemustaka tentang fasilitas layanan bagian referensi dengan kepuasan pemustaka;

Pernyataan yang menunjukkan hubungan fasilitas layanan mengenai alat penelusuran informasi mendapatkan respon paling tinggi. Hal ini menunjukkan bahwa layanan bagian referensi CISRAL Unpad memiliki alat penelusuran informasi $(O P A C)$. Sedangkan pernyataan kemutakhiran koleksi yang tersedia mendapatkan respon paling rendah. Hal ini menujukkan bahwa koleksi yang terdapat pada layanan bagian referensi CISRAL Unpad tidak mutakhir yang berarti koleksi-koleksi tersebut kurang up to date.

Penjelasan diatas sesuai dengan Hasugian (2003:hlm.9) menyatakan bahwa"... OPAC adalah katalog yang paling cocok saat ini digunakan di perpustakaan. $O P A C$ jauh lebih melebihi katalog kartu dan katalog lainnya yang digantinya". Katalog kartu memiliki sejumlah keterbatasan dibadning dengan $O P A C$. Sekalipun fungsi dasarnya sama yaitu sebagai sarana temu kembali di perpustakaan, namun diantara katalog kartu dan $O P A C$ terdapat banyak perbedaan.

Kepuasan pemustaka merupakan salah satu indikator keberhasilan layanan bagian referensi perpustakaan. Menurut Hasugian (2003: 9) umunya pengguna mengakui bahwa ada tingkat kepuasan yang tinggi dengan $O P A C$. “...pengguna lebih menyukai $O P A C$ karena: a. Menelusur di $O P A C$ menyenangkan; b. Menelusur di OPAC Menghemat waktu; c. $O P A C$ menyediakan layanan baru; dan d. $O P A C$ menyediakan ciri khas yang baru Markey".

4) Hubungan persepsi pemustaka tentang tata ruang layanan dengan kepuasan pemustaka.

Pernyataan yang menunjukkan hubungan tata ruang layanan yang sederhana memiliki hubungan dengan ketidakpuasan pemustaka mendapatkan respon paling tinggi. Hal ini menunjukkan bahwa layanan bagian referensi CISRAL Unpad telah menyediakan ruangan yang memadai. Sedangkan untuk pernyataan temparatur suhu yang stabil mendapatkan responden paling rendah mengenai peyediaan temparatur suhu yang stabil.

Penjelasan diatas sesuai dengan apa yang dikemukakan oleh Suwarno (2011: hlm.42) yaitu “...gedung perpustakaan merupakan salah satu sarana atau fasilitas yang amat penting dalam penyelenggaraan perpustakaan". Dan sebagai fasilitas layanan, maka gedung perpustakaan harus memperhatikan kemudahan arus pergerakan manusia sebagai pemustaka perpustakaan. Selain itu perpustakaan harus memiliki ruangan yang sejuk, nyaman, hawa dingin.

5) Hubungan Persepsi Pemustaka Dengan Kepuasan Pemustaka Pada 
Layanan Perpustakaan CISRAL Unpad.

Berdasarkan hasil pengujian hipotesis melalui uji korelasi yang dilakukan menunjukkan bahwa, terdapat hubungan persepsi pemustaka dengan kepuasan pemustaka perpustakaan CISRAL Unpad yakni berada pada interpretasi sedang dan signifikan.

Interpretasi sedang dan signifikan menunjukkan bahwa terdapat hubungan antara persepsi pemustaka dengan kepuasan pemustaka dan hubungan tersebut memiliki arti atau makna, berarti hubungan antara keduanya memiliki hubungan timbal balik.

Persepsi pemustaka memiliki hubungan kuat terhadap kepuasan pemustaka perpustakaan. Hal ini dilihat dari pengukuran terhadap indikatorindikator yang digunakan, yaitu aspek ketersediaan koleksi, kompetensi pustakawan layanan perpustakaan, fasilitas perpustakaan layanan bagian referensi, tata ruang layanan perpustakaan layanan bagian referensi. Dengan demikian pengujian hipotesis yang dilakukan menunjukkan bahwa $\mathrm{H}_{0}$ ditolak dan $\mathrm{H}_{1}$ diterima, hal ini berarti terdapat hubungan yang signifikan antara persepsi pemustaka dengan kepuasan pemustaka layanan bagian referensi CISRAL Unpad.

Hubungan antara indikator persepsi pemustaka dengan kepuasan pemustaka layanan bagian referensi CISRAL Unpad yakni indikator ketersediaan koleksi dan kompetensi pustakawan layanan bagian referensi memiliki hubungan yang kuat dengan kepuasan pemustaka. Fasilitas perpustakaan layanan bagian referensi dan tata ruang layanan bagian referensi CISRAL Unpad memiliki hubungan yang sangat kuat terhadap kepuasan pemustaka.

\section{SIMPULAN}

Dari hasil Penelitian ini dapat disimpulkan bahwa Hubungan persepsi pemustaka tentang ketersediaan koleksi referensi dengan kepuasan pemustaka; ketersediaan koleksi mengenai rujukan non cetak dalam kategori paling tinggi. Hal ini menunjukkan bahwa layanan bagian referensi CISRAL Unpad memiliki koleksi rujukan non cetak yang baik. Sedangkan kemutakhiran koleksi yang tersedia mendapatkan respon paling rendah hal ini menujukkan bahwa koleksi yang terdapat pada layanan bagian referensi CISRAL Unpad tidak mutakhir yang berarti koleksi-koleksi tersebut kurang up to date.

Berdasarkan hasil penelitian yang dilakukan untuk mengetahui hubungan persepsi pemustaka dengan kepuasan pemustaka layanan referensi CISRAL Unpad yang meliputi ketersediaan koleksi, kompetensi pustakawan layanan, fasilitas layanan referensi, dan tata ruang layanan referensi, maka dapat diambil kesimpulan bahwa persepsi pemustaka tentang layanan bagian referensi 
berhubungan sedang dengan kepuasan pemustaka pada layanan referensi di CISRAL Unpad. Hal ini ditunjukkan oleh ketersediaan koleksi, kompetensi pustakawan layanan, fasilitas layanan referensi, dan tata ruang layanan referensi.

Kepuasan pada layanan referensi CISRAL Unpad, tidak hanya memiliki hubungan dengan persepsi pemustaka saja, tetapi ada faktor lain (error). Faktor lain tersebut seperti faktor lingkungan, kebijakan dan lain sebagainya. Dengan demikian $\mathrm{H} 1$ diterima yang berarti persepsi pemustaka tentang layanan bagian referensi memiliki hubungan yang signifikan dengan kepuasan pemustaka pada layanan CISRAL di Unpad.

Berikut kesimpulan dari hasil pengujian persepsi pemustaka terhadap kepuasan pemustaka terdapat suatu hubungan yang kuat dan signifikan, hal ini menunjukkan bahwa untuk menunjang pelayanan perpustakaan pada layanan bagian referensi hendaknya dapat memenuhi kebutuhan para pemustaka yang dapat dilihat dari beberapa aspek misalnya dlihat dilihat dari ketersediaan koleksinya yang dapat memberikan bantuan kepada pemustaka dalam menemukan informasi, fasilitas yang mendukung proses pencarian informasi, cepat tanggapnya pustakawan terhadap pemustaka, serta memiliki tata ruang yang memadai sehingga memudahkan pemustaka bergerak dan mencari informasi.

\section{DAFTAR PUSTAKA}

Pareek, Udai. (1991). Perilaku Organisasi. Jakarta: Karya Unipress.

Suwarno, Wiji. (2010). Dasar-Dasar Ilmu Perpustakaan. Jakarta: Ar Ruzmedia

Yulia, Yayu. (2009). Pengembangan

Koleksi;1-9. Cetakan 6. Jakarta:

Universitas Terbuka.

Yusup, Pawit M. (1995). Pedoman Praktis Mencari Informasi. Bandung: Remaja Rosdakarya.

Universitas Pendidikan Indonesia. (2012). Pedoman Penulisan Karya Ilmiah. Bandung: UPI.

Sumber online

Hasugian, Jonner. (2003). Katalog

Perpustakaan: Dari Katalog Manual Sampai KAtalog Online (OPAC) [Online]. Tersedia: Juni 2013].

Kamus Besar Bahasa Indonesia. (2009).

Persepsi [Online]. Tersedia: http://pusatbahasa.diknas.go.id/kbbi/ index.php [12 Mei 2013].

Menuju Kepuasan Pemustaka - Jurnal Ilmu Informasi dan Komunikasi. .. [ O n $1 \mathrm{ine}$ ]. T e r s e d i a : http://wwwfiles.palimpsest.fisip.unai r.ac.id/images/pdf/achmad.pdf [17 Juli 2013].

Undang-Undang Indonesia Nomor 2

Tahun 2007 tentang Perpustakaan. Jakarta: 
Perpustakaan Nasional.

Undang-Undang Republik Indonesia.

(2007). No. 43 Tahun 2007

Tentang Perpustakaan [Online].

Tersedia:http://wwwfiles.perpusnas.

go.id/homepag/activities/highlight/ru

u_perpustakaan/pdf/UU 43 2007_P

ERPUSTAKAAN.pdf [26 Mei

2013].

Undang-Undang Republik Indonesia.

(2003). No. 20 Tahun 2003

Tentang Sistem Pendidikan

Nasional [Online]. Tersedia:

http://wwwfiles.perpusnas.go.id/hom

epag/activities/highlight/ruu_perpust

akaan/pdf/UU $43 \quad 2007$ PERPUST

AKAAN.pdf 